states. Primarily set up for flood control, the TVA also, under Lilienthal's guidance, brought affordable electricity generated by its hydroelectric plants to American farm communities and towns. In the 1920s and 1930s, a vast number of US farmers had deplorable living conditions, without electricity or clean water. The lack of electricity stemmed not from an inability to generate it, but from the cost of delivering it using long-distance transmission lines. Schewe chronicles Lilienthal's behindthe-scenes political machinations against the opposition of the investor-owned power industry as he sought to realize his dream of a completely electrified America.

There is no doubt that the TVA and other federal rural electrification efforts were outand-out welfare projects funded at public expense in the finest traditions of a socialist state. But they were also one of the best investments the nation ever made on behalf of its citizens. Lilienthal had expanded Insull's minigrid to a national scale, bringing electricity to Americans everywhere. The lives of these two men reveal that society benefits from both private and public investment in the electricity enterprise. The challenge is to strike the appropriate balance.

Today the US grid and its clones in Europe, Asia and South America are in trouble. Collapses and power failures occur everywhere on an almost yearly basis, and Schewe exposes many examples in depressing detail. In the United States, the average price of electricity continues to rise along with fuel prices. Only nuclear-generated power has been stable in terms of consumer cost, and in some states it has declined significantly. Deregulation has not worked. In 2001, problems with electricity supply brought down California's governor and severely damaged the state's economy. Considering electricity as a commodity strains the laws of both physics and economics. Unlike corn, gas, precious metals and jet airliners, electricity is difficult to park somewhere until demand for it ripens. It is best used as soon as it is made. And restructuring the industry has left the grid in the dark. Who now should be responsible for its maintenance, expansion and improvement?

Schewe discusses all the current 'hot' issues affecting the grid and the electricity industry in general. There are thorough discussions of renewable energy sources, energy efficiency, the emission of noxious $\left(\mathrm{SO}_{2}\right)$ and non-noxious $\left(\mathrm{NO}_{x}, \mathrm{CO}_{2}\right.$ ) gases, heavy metals (mercury and thallium), nuclear safety, the siting of infrastructure and other environmental concerns. The author points out the growing demand for electricity worldwide, and the balance that must be struck between improving the human condition and damaging the Earth.

The Grid sets the scene but offers little in the way of solutions. However, that wasn't the intent. The book is an outstanding historical narrative and commentary on the grid past and present, and is a valuable contribution to understanding its future challenges. Having said that, I wish more detailed discussion had been included on a few promising technologies already on the shelf, such as high-power electronics and superconductivity. The former, mentioned briefly in the context of a 'smart grid', has the potential to drastically reduce the occurrence of large-scale power failures by deploying a combination of sensors, computation and hockey-puck-size silicon switches to create detours around circuit roadblocks when the electron traffic jams up. And we could start implementing it right now. It would be costly, but so was the TVA and rural electrification. What's lacking today is the political will of the past to make the smart grid an investment for the public good.

Paul M. Grant is a visiting scholar at Stanford

University, California, and a retired science fellow at the Electric Power Research Institute.

\title{
The stem-cell story
}

\section{Stem Cell Now: A Brief Introduction to the \\ Coming Medical Revolution \\ by Christopher Thomas Scott \\ Plume: 2007.272 pp. $€ 9.99$}

Cell of Cells: The Global Race to Capture and Control the Stem Cell

by Cynthia Fox

W. W. Norton: 2006.512 pp. \$26.95, £16.99

Stem Cell Wars: Inside Stories from the

Frontlines

by Eve Herold

Palgrave MacMillan: 2006. 256 pp.

$\$ 24.95, £ 15.99$

\section{Justine Burley}

The promise of stem-cell research has captured the imagination of people around the world. Given the public's intensifying interest in the area, it was perhaps inevitable that stemcell science would enter the 'popular science' genre. Books of this sort can excite people about research in general, acquaint them with recent developments in a specific field, equip non-specialists with factual knowledge, serve as a resource for patients or politicians, and update scientists on the rough-and-tumble of their own discipline. Rarely does a single work succeed in doing all these things well, even when that is the author's aim. And so it is with three new books about stem cells.

Christopher Scott's little book Stem Cell

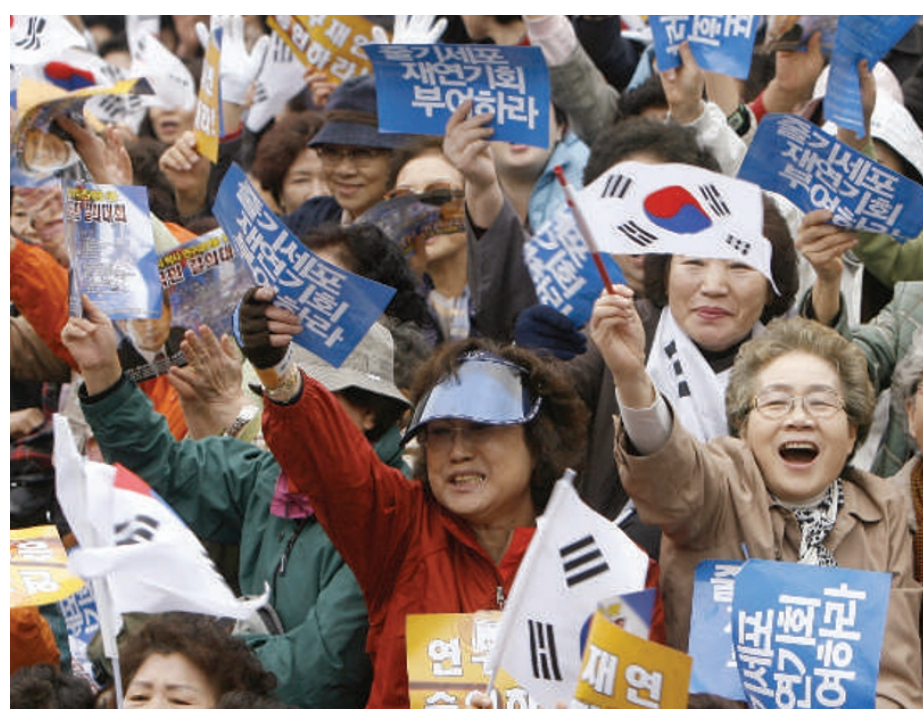

Now is fundamentally a primer on stem-cell research, suitable for lay readers and freshmen. It offers accessible descriptions of stem-cell science and analysis of associated ethical and political issues. Discussion of these aspects is sweeping and incomplete, but this is no pitfall for anyone seeking a grounding in the basics. The strongest chapters, which make up the first half of the book, are those dealing with factual knowledge: the properties of stem cells, their potential applications and apparent limitations. Responsibly, Scott is circumspect about existing evidence for the plasticity of certain sorts of adult stem cell; he advances no exaggerated claims about the current state of the art in human embryonic stem-cell research; and he makes plain that cell therapy is not the sole contribution it can make to human medicine.

Cynthia Fox's Cell of Cells is a rather big book that will be of most interest to those working in the stem-cell field. This fast-paced, journalistic, not-without-depth treatment of the issues (again, scientific, ethical and political) is peppered with gossip but still manages to be serious. As a presentation of developments in stem-cell research between 2003 and 2006, the book is already rather dated, but it is informative and provides insight into the shape of things to come. The author mounts a persuasive case for the need to conduct research using both embryonic and adult stem cells, and
Stem-cell researcher Woo Suk Hwang remained popular at home in Korea despite publishing fraudulent data. 
pointedly takes to task religious groups and others who are opposed to the use of embryos in research. The portrait that Fox paints of stem-cell science and politics, and of the talented (sometimes flawed) individuals involved, is faithful to reality. She pitches her account squarely in the context of competition between individual scientists, labs and nations, not all of which have been proceeding honourably in the race to revolutionize medicine using stem cells. Few of the mainstream players are missed out. An entire chapter, 'Biopolis', is dedicated to Singapore (where I am based), which punches well above its weight in the stem-cell field. The Biopolis, a conglomeration of glamorous institutes with a world-class infrastructure, is just one of many places where Fox conducted a vast number of interviews, attended conferences and generally did her homework. The author has laboured to be thorough, and tells an interesting story.

Eve Herold's Stem Cell Wars is a good resource for patients and is also appropriate for lay readers. It is light on science but heavy on compassion and good sense. The bulk of Herold's discussion of the ethical and political controversies surrounding stem-cell research is confined to the United States, where policymakers have shamelessly played into the hands of well-organized, well-funded, 'pro-life' lobbyists. Herold does a fine job of bringing to the fore the way that religiosity continues to polarize the nation with respect to all matters concerning the moral status of early human life. Herold, like Fox and Scott, dedicates pages to the stem-cell fraud perpetrated by Woo Suk Hwang in South Korea. None of the authors, it must be said, adds much that is new on the affair, which was comprehensively covered at the time by several science writers, notably Nature's David Cyranowski (see, for example, Nature 438, 1056-1057; 2005).

The principal themes that surface in these three books are now familiar. First, there has been a mischievous use of facts by opponents of embryonic stem-cell research. The wilful misunderstanding of important differences between adult and embryonic stem cells has skewed the moral debate and stalled progress. Second, researchers using adult and embryonic stem cells face major technical challenges, some of which may be insurmountable, and it remains doubtful whether either stem-cell type will be the medical panacea that some have proposed. Third, scientists operate in a fiercely competitive environment - reputations stand or fall on the basis of publications and the grant money required to get them. Against this background, it is unsurprising that frauds have been committed and that sloppy science has seeped into some top-tier journals. Finally, it is a fact that every day, people around the world become ill, suffer and die. Despite this, many misguided citizens seek to use governments to impose on others their own particular metaphysical conceptions of the sacredness of human life. No essentially religious view should dominate policy in a modern democratic society.

Those interested in stem cells should be mindful of what they hope to gain from their reading before cracking the spine of any of these books. Each has something to offer, but no one book is tailored for everyone. Justine Burley is at the Graduate School for Integrative Sciences and Engineering, National University of Singapore, Singapore 117456, Singapore.

\section{Flight of the dinosaur}

\section{Glorified Dinosaurs: The Origin and Early Evolution of Birds by Luis Chiappe \\ University of New South Wales Press/John Wiley: 2007. 272 pp. Aus $\$ 59.95 / £ 38.95$, US\$56}

\section{Angela Milner}

Dinosaurs: you have seen them, heard them (especially in spring) and you have probably eaten them. They did not all die out 65 million years ago as a result of an asteroid impact, as the media would generally have us believe. No, dinosaurs are all around us, and there are some 10,000 living species. They are, of course, birds. As Luis Chiappe so graphically illustrates in his book Glorified Dinosaurs, birds are small, feathered theropod dinosaurs.

In the past decade the evolution of birds from small meat-eating dinosaurs has been established beyond all reasonable doubt, thanks to some thrilling discoveries of new fossils and the radical reinterpretation of some others known since the late nineteenth century. Here, Chiappe presents a comprehensive and up-to-date summary of the exciting research that has revolutionized our understanding of the origin and evolution of the only other group of endothermic animals beside mammals that share our planet. In a lively, readable and accessible style, he takes the reader through the historical background, stresses the evolutionary relationships and the physical and functional changes from terrestrial predatory dinosaurs through to modern airborne birds.
Chiappe deals with issues of controversy and debate their dinosaurian forebears must also in a clear and straight-

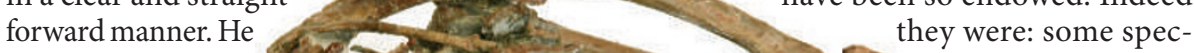

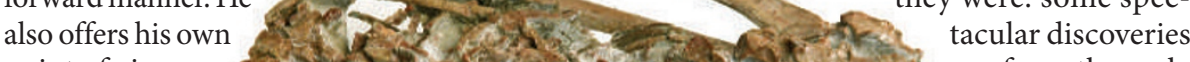
point of view on several hot topics, notably the earliest appearance of modern orders of birds in the Mesozoic era, and how powered, flapping flight came about.

In the $1860 \mathrm{~s}$, T. H. Huxley concluded, on the limited fossil evidence then available, that birds were nothing more than glorified dinosaurs. But other views subsequently prevailed, notably that birds stemmed from early archosaurs, although there were no candidate fossils. Huxley's hypothesis was revived and really took off in the 1960s with the discovery by John Ostrom of a small, highly agile and remarkably bird-like predatory dinosaur that he named Deinonychus. Since then, a wealth of skeletal evidence has accumulated in support of the view that birds originated from within a group of small terrestrial theropods, now termed maniraptorans (the raptors of popular books and films). The sheer number of shared characters between maniraptorans and early birds is compelling and has formed the basis of repeated hypothesis testing by rigorous cladistic methods. The results have convinced all but the tiniest band of ornithologists.

An inevitable corollary of the dinosaur-bird relationship is that, as birds are feathered, their dinosaurian forebears must also $\stackrel{\cong}{\exists}$ from the early 1990s onwards in Lower Cretaceous deposits in Liaoning province in China have revealed in exquisite detail a range of feathery coverings in several small theropod lineages. They range from simple filamentous protofeathers, which hint that the development of feathers was primarily for insulation, to small maniraptorans clad from head to knees in vaned contour feathers and tail plumes, just like modern birds. The remarkable preservation, which happened, like the burial of Pompeii, as a result of sudden inundation by volcanic ash and tuff, has provided the final pieces of evidence in the story of bird origins. Feathers were undoubtedly present a long way back down the theropod family tree but they are preserved only under these exceptional 'Lagerstätten' conditions.

One of the strong points of this book is that it is profusely illustrated, in full colour throughout, with more than 220 illustrations of fossils, including many of the spectacular 